\title{
Effect of Learning CD Based on the SAVI (Somatic Auditory Visual Intellectual) Approach to Student Learning Outcomes on the Concept of Global Warming
}

\author{
Devi Solehat $^{1}$, Ai Nurlaela ${ }^{2}$, F.N. Fauzia ${ }^{3}$ \\ $\left\{\underline{\text { devi.sholehat@uinjkt.ac.id }}\right.$, $\underline{\text { ai.nurlaela@uinjkt.ac.id }}$, $\left.\underline{\text { fathiafauzia72@ gmail.com }}{ }^{3}\right\}$
}

UIN Syarif Hidayatullah Jakarta, Indonesia ${ }^{1,2.3}$

\begin{abstract}
This study aims to determine the effect of the application of learning CD media based on the SAVI approach (Somatic Auditory-Visual Intellectual) on students learning outcomes on the concept of symptoms of global warming. This research was carried out at 11 Bekasi Senior High School in March 2019. The research method used was a quasiexperimental design with a nonequivalent control group design. The sample in this study was taken by purposive sampling which consists of class XI MIA 3 (experimental class) and class XI MIA 4 (control class). The instruments used were test instruments in the form of essays and non-test instruments in the form of questionnaires. Based on the results of the hypothesis testing of the posttest data by using the parametric statistical test in the form of the t-test at a significance level of 0.05 , the sig value was obtained. (2tailed) of 0.001 which means that sig. $<0.05$, then $\mathrm{H} 0$ is rejected and $\mathrm{H} 1$ is accepted, with the learning CD-based mechanism of the SAVI Approach proven to influence student Learning Outcomes on the concept of symptoms of global warming. In addition, the overall response of students also shows excellent responses with an average percentage value of $81 \%$
\end{abstract}

Keywords: Learning CD; (Somatic Auditory-Visual Intellectual Approach; Learning outcomes; symptoms of global warming.

\section{Introduction}

Education is a way to gain knowledge. Basically, science is discovered, formed, and developed by students themselves actively in the learning process in the classroom and outside the classroom [1]. With education, students can cause changes in themselves so that they play an active role in the learning process.

This time in the classroom learning process is still dominated by a teacher-centered approach (Teacher center). The teacher has not provided access for students to develop independence through discovery in their thought processes [2]. So that teaching and learning activities make students not play an active role and not produce many ideas that ultimately affect student learning outcomes and this is evidence that Indonesia is still lagging behind in the field of science.

Learning style is the easiest way that is owned by individuals in absorbing, organizing, and processing information received. Every student has their own learning style but cannot be activated in school because the learning process tends to be difficult to regulate the learning styles of all students in the classroom. If students understand their learning styles and learn according to their learning styles, and choose appropriate teaching materials, then they will get better achievement [3]. Therefore, we need a media and learning approach that can activate all student learning styles. Media and approaches that are suitable for activating the entire 
learning style of students one of them with CDs based on the SAVI approach. The advantage of learning CDs is that students can study independently, not depending on the teacher [4].

One approach that concerns students' learning styles is SAVI (Somatic, Auditory, Visual, Intellectual) because in this approach learning uses the senses of the body such as listening, speaking, seeing and concentration of the mind and then practice using it through reasoning is the best way of learning if everything is used simultaneously [5]. 
The use of media and learning approaches by activating all learning styles can support students to create learning conditions that deliver students to be able to understand the concepts of global warming symptoms and be aware of the surrounding environment so as to achieve optimal learning outcomes.

Environmental problems that occur at this time are the responsibility of all elements of society are expected to instill the young generation of heirs of the earth to love the environment for the sake of the continuity of life on earth [6]. One of the causes of global warming is the increased concentration of greenhouse gases caused by human activities. Awareness and care to follow up are needed to respond to the consequences of global warming [7]. With environmental problems that occur students must be able to realize and care early on from the effects of global warming in order to find the right way to deal with it.

\section{Research Methods}

In this study, the method used was a quasi-experimental method (Quasi-Experimental Design). The research method with this design has a control group, but it cannot function fully to control the external variables that influence the implementation of the experiment. This method is used to examine the possible influence of learning CD media based on the SAVI Approach by providing treatment to the experimental group then the results are compared with the control group.

The design used in this study is a nonequivalent control group design to determine student learning outcomes before and after learning is treated by using a learning CD based on SAVI Approach.

In this design, the experimental group and the control group were not randomly selected. The two groups used as a sample will be applied to different treatments and selected on the basis of certain considerations so that the level of homogeneity between groups is relatively the same.

The first group was treated with the learning CD learning media based on the SAVI Approach as an experimental group while the second group was made a control group with a conventional learning approach in accordance with what is commonly used by teachers in the school where the research took place.

Both groups will be given a pre-test (pretest) before treatment and a final test (Posttest) after the treatment and the results of the two groups are compared by the researcher. This study design can be seen in the draft as follows:

Table 1. Research Design

\begin{tabular}{|l|l|l|l|}
\hline Group & Pretest & Treatment & Posttest \\
\hline Experimental & $\mathrm{O}_{1}$ & $\mathrm{X}_{1}$ & $\mathrm{O}_{2}$ \\
\hline Control & $\mathrm{O}_{1}$ & $\mathrm{X}_{2}$ & $\mathrm{O}_{2}$ \\
\hline
\end{tabular}

There are three stages in the data collection techniques in this study, namely the first stage by conducting interviews with several physics teachers in Bekasi City to find out the learning process carried out and student learning outcomes. In the second stage when the learning takes 
place by giving tests to the experimental and control groups. A test is a collection of questions or exercises that are used to measure a person's knowledge, skills and talents.

The test used in the form of a pretest given before treatment and posttest given after applying the learning CD based on the SAVI Approach in the experimental group and conventional learning approach in the control group. Then the third stage is after learning to use data collection techniques in the form of non-tests (not tests) with a questionnaire method that aims to see student responses to learning using learning CDs based on the SAVI Approach to the experimental group.

Data analysis techniques used in this study include test data analysis and non-data data analysis. Before testing the research hypothesis, a prerequisite test was conducted which included a normality test with the Shapiro Wilk test and a homogeneity test with the test Levene using Software SPSS. 


\section{Result and Discussion}

Results of the data obtained during the study in the experimental class and the data control class described are the result of the pretest and posttest from both classes. The results of the study are described in the following table:

Table 2. Summary of the results of pretest and posttest Experiment Class and Class Control

\begin{tabular}{|l|c|c|c|c|}
\hline \multicolumn{1}{|c|}{ Convergence and } & \multicolumn{2}{c|}{ pretest } & \multicolumn{2}{c|}{ posttest } \\
\hline \multicolumn{1}{|c|}{ Data Dissemination } & $\begin{array}{c}\text { Experiment } \\
\text { Class }\end{array}$ & $\begin{array}{c}\text { Control } \\
\text { Class }\end{array}$ & Class Experiment & $\begin{array}{c}\text { Class } \\
\text { Control }\end{array}$ \\
\hline Lowest Value & 26.00 & 26.00 & 46.00 & 36.00 \\
\hline Value Highest & 76.00 & 80.00 & 96.00 & 93.00 \\
\hline Average & 51.92 & 62.47 & 71.44 & 62.47 \\
\hline Mode & 56.00 & 60.00 & 70.00 & 70.00 \\
\hline Median & 53.00 & 56.00 & 71,50 & 60.00 \\
\hline Standard Deviation & 11.32 & 16.26 & 13.44 & 16.26 \\
\hline
\end{tabular}

Based on Table 2 above it can be seen that student learning outcomes are relatively low. It can be seen from the achievement of the average value pretest for the experimental class of 51.92 and the control class of 62.47. Some factors that cause low student learning outcomes are teaching and learning activities with a teacher-centered approach (teacher center) so that students do not play an active role and do not produce many ideas. During this time the learning process of physics in the classroom, especially on the concept of global warming, tends to be less than optimal. This resulted in low student learning outcomes. Student learning outcomes will improve if learning is interesting, activities throughout the body, involving all the senses, and considering the learning styles of each student are different [8].

Student learning outcomes improved after being given different treatment in each class. The increase was seen in the average score posttest obtained. In the experimental class given treatment in the form of learning by using learning CDs based on the SAVI approach obtained an average value of 71.44. Whereas in the control class there was no change in the increase in the average value or equal to the average value pretest of 62.47 . Based on these data it can be concluded that the experimental class learning outcomes that use learning CDs based on the SAVI approach are superior compared to the control class. On the learning CD there is a syntax or stages of the SAVI approach that contains elements somatic, auditory, visual, and intellectually with syntax that has several advantages compared to conventional learning approaches, so as to optimize student learning outcomes.

This is because, at the delivery stage in the learning CD, students can be trained to be able to ask questions and express their arguments through the sheets that have been provided. in applying the SAVI Approach, students are given the opportunity to learn independently at the training stage. Somatic is a body movement that requires learning by doing and doing. The process of learning while listening, talking, presenting, debating, and responding. Visual is learning by using sensory meta through collecting, drawing, showing, reading, using media, and teaching aids [9].

At this stage, students are trained to get used to analyzing knowledge based on evidence so that students experience what they are learning. 
Students are also required to learn auditory by finding solutions to the problems contained in the learning $\mathrm{CD}$ through discussion, asking questions and expressing their arguments. Furthermore, students are trained to rethink concepts learned by utilizing their intellect in solving a problem.

In connection with the stages of SAVI that have been described, an increase in learning outcomes using learning CDs based on the SAVI approach. The strengths of the SAVI approach include (a) generating full integrated student intelligence through the incorporation of physical motion with intellectual activity, (b) creating a better, interesting and effective learning atmosphere, c) able to arouse creativity and enhance students' psychomotor abilities, (d) maximizing the sharpness of student concentration through visual, auditory and intellectual learning, (e) learning is more interesting with the learning game, (f) the approach offered is not rigid but can vary greatly depending on the subject matter, and the learning itself, and $(\mathrm{g})$ can create a positive learning environment [10]. The results of students' final abilities based on the cognitive domain as a whole the experimental class is superior to the control class can be seen in the table below.

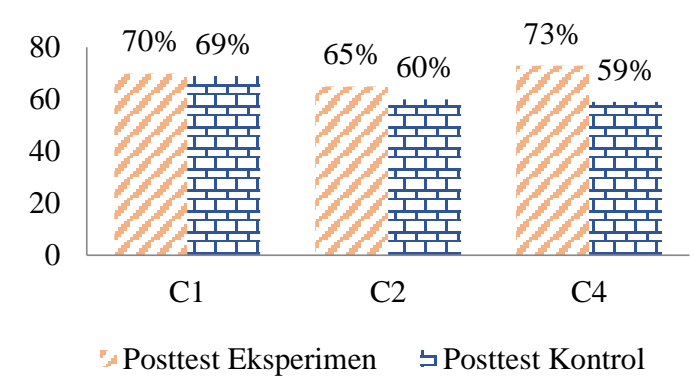

Fig 1. Data Posttest Learning Outcomes of the Experimental Class and Control Class

$\mathrm{C} 1$ cognitive domain is presented as an animated video related to the symptoms of global warming so that students become easier to remember learning. $\mathrm{C} 2$ cognitive domain, namely instructing students to compare temperatures inside and outside the room so that students can more easily understand the concept of global warming symptoms.

C4 cognitive domain that is presented an image related to global warming so students are able to analyze the phenomena that occur related to global warming symptoms. The results of the largest percentage of the three cognitive domains used are in the realm of analysis $(\mathrm{C} 4)$ of $73 \%$. This proves that learning CD based on the SAVI approach can improve students' cognitive abilities.

The results of the normality test of the results pretest and posttest in this study using the Shapiro Wilk test with the help of Software are SPSS declared normally distributed with the provisions of the data distribution normally distributed if the value of sig. $>0.05(5 \%)$ then $\mathrm{H}_{0}$ accepted.

Table 3. Results of the calculations normality test data pretest and posttest

\begin{tabular}{|c|c|c|c|c|}
\hline \multirow{2}{*}{ Statistics } & \multicolumn{2}{|c|}{ Pretest } & \multicolumn{2}{c|}{ Posttest } \\
\cline { 2 - 5 } & Experiment Class & Control Class & Experiment Class & Control Class \\
\hline Df & 36 & 36 & 36 & 36 \\
\hline Sig. (2-tailed) & 0.368 & 0.302 & 0.246 & 0.302 \\
\hline
\end{tabular}




\begin{tabular}{|l|l|l|}
\hline Level of significance $(\boldsymbol{\alpha})$ & 0.05 & 0.05 \\
\hline
\end{tabular}

Results Homogeneity Test uses test Levene with the help of Software SPSS. Homogeneity test decision making is based on the terms of testing the homogeneity hypothesis that is if the value of sig. $\geq 0.05$ then $\mathrm{H}_{0}$ is accepted, the data revealed to have the same variance (Homogeneous). It can be seen in the following table.

Table 4. Results of homogeneity test calculationsdata pretest and posttest

\begin{tabular}{|c|c|c|}
\hline Statistics & $\begin{array}{l}\text { pretest Experiment } \\
\text { ClassandControl Class }\end{array}$ & $\begin{array}{c}\text { posttest Class Class Experiment } \\
\text { and Control }\end{array}$ \\
\hline Levene Statistic & 0.685 & 0.396 \\
\hline Level of significance $(\boldsymbol{\alpha})$ & \multicolumn{2}{|c|}{0.05} \\
\hline Conclusion & Second Class Homogeneous & Second Class Homogeneous \\
\hline
\end{tabular}

Based on statistical analysis prerequisite test, obtained information that the data pretest and posttest are normally distributed and have the same variant. Therefore, the use of parametric statistical test analysis in the form of a t-test is carried out for hypothesis testing. Hypothesis test results can be seen in the table below:

Table 5. Hypothesis Test Data Pretest and Posttest

\begin{tabular}{|c|c|c|}
\hline Statistics & pretest & posttest \\
\hline Sig. (2-tailed) & 0.168 & 0.001 \\
\hline Level of significance $(\alpha)$ & & 0.05 \\
\hline Conclusion & Ho $_{\text {occepted }}$ & $\mathrm{H}_{\mathrm{a}}$ accepted \\
\hline
\end{tabular}

Research conducted has several advantages and disadvantages. Of the several advantages that have been described, there are some weaknesses in the use of learning CDs that are found when learning at school.

First, learning CDs can only be operated using computer equipment in the school computer lab that is prepared by each student and requires time to prepare so as to reduce the effective time of learning.

Second, there are differences in the time of completion of the use of learning CDs on each student, so that makes students who have finished learning using the learning CD must wait for other students who have not finished so that the learning planning stages are carried out simultaneously. Nevertheless, the use of learning CDs in the learning process has been able to improve student learning outcomes and get positive responses from students.

The positive attitude of students towards learning the symptoms of global warming by using a learning CD based on the SAVI Approach is shown in the table below:

Table 6. Student Questionnaire Results

\begin{tabular}{|l|l|c|c|}
\hline No. & \multicolumn{1}{|c|}{ Indicator Questionnaire } & Percentage & Category \\
\hline 1. & Use of learning CDs based on SAVI Approach & $81 \%$ & Excellent \\
\hline 2. & Student Learning Outcomes & $80 \%$ & Excellent \\
\hline
\end{tabular}




\begin{tabular}{|c|c|c|c|}
\hline 3. & Submission of Concept material & $82 \%$ & Excellent \\
\hline Average & $81 \%$ & Excellent \\
\hline
\end{tabular}

The results of student questionnaire responses overall received responses that were excellent with a percentage of $81 \%$. In addition, the results of the questionnaire were also known that students agreed that the use of learning CDs could improve learning outcomes.

This shows that the learning CD can be a solution to the problem of the lack of active students in the learning process that makes students become bored in learning and teachers can optimize student learning outcomes. That is, overall the use of learning CDs in the learning process can have a positive influence on student learning outcomes, especially on the concept of global warming symptoms.

\section{Conclusion}

Based on the results of research and discussion, it can be concluded that:

a. The learning CD based on the SAVI approach influences student learning outcomes on the concept of global warming symptoms. The influence is evident from the results of hypothesis testing which obtained sig values. (2-tailed) $(0,001)<$ significance level value $(0,05)$.

b. Improved learning outcomes of the experimental class are higher than the control class. This is evidenced by the average value of $\mathrm{N}$-Gain in the experimental class that is superior to the control class. N Gain is the experimental class in the medium ategory and the control class in gthe low category.

c. The response of students to lerning CDs based on the SAVI Approach in the learning process on the concept of global warming symptoms as a whole received an excellent response of $81 \%$.

\section{References}

[1] Fitriyaningsih. "Penerapan Pendekatan Somatic, Auditory, Visual, Intellrctualy (SAVI) Untuk Meningkatkan Motivasi dan Hasil Belajar Fisika Siswa Kelas XI di SMA Negeri 3 Boyolali Tahun Pelajaran 2012/2013," Jurnal Pendidikan Fisika., vol. 2, no. 2, pp. $31,2014$.

[2] Trianto Ibnu Badar Al-Tabany. Mendesain Pendekatan Pembelajaran Inovatif, Progresif, dan Kontekstual. (Jakarta: Prenadamedia Group). 2014. pp. 6.

[3] Purmadi, Ary and Surjono, H. D. "Pengembangan Bahan Ajar Berbasis Web Berdasarkan Gaya Belajar Siswa untuk Mata Pelajaran Fisika," Jurnal Inovasi Teknologi Pendidikan., vol. 3, no 2, pp. 153, 2016.

[4] Lestari C, Djamas D , and Murtiani. "Pengaruh Compact Disk (CD) Multimedia Interaktif dalam Model Problem Based Learning Berbantuan LKPD Terhadap Critical Thinking Skill Peserta Didik Kelas X Sman 1 Padang," Jurnal Pillar of Physics Education., vol. 9, pp. 10. 2017.

[5] Dave Meier. The Accelerated Learning Handbook. 2002. pp. 91-92

[6] Afandi, Rifki. "Integrasi Pendidikan Lingkungan Hidup Melalui Pembelajaran IPS di Sekolah Dasar Sebagai Alternatif Menciptakan Sekolah Hijau," Jurnal Pedagogia., vol.2 no.1, pp. 100, 2013.

[7] Wuryandari A dan Akmaliah M. "Game Interaktif Mencegah Terjadinya Pemanasan Global Untuk Anak,” Jurnal SIMETRIS., vol.7, no.1, pp. 311, 2016.

[8] Satria, Erwinsyah. "Improving Students' Activities And Learning Outcomes In Natural 
Science In Class V By Using Somatic Auditory Visual Intellectual (SAVI) with Science Kit Seqip," Proceeding ICOMSET, pp. 387, 2015.

[9] U. Umayah, Supriadi, and Mulyono, S. E. "Implementation of SAVI Learning Model Through Practicum Activities Towards Students Science Learning Outcomes," Journal of Primary Education, vol 9, no. 2, pp. 184, 2019.

[10] Sarnoko, Ruminiati, and Setyosari, Punadji. "Penerapan Pendekatan SAVI Berbantuan Video Pembelajaran Untuk Meningkatkan Aktivitas Dan Hasil Belajar IPS Siswa Kelas IV SDN I Sanan Girimarto Wonogiri," Jurnal Pendidikan: Teori, Penelitian, dan Pengembangan, vol 1, no. 7, pp. 1236, 2016. 